Check for updates

Cite this: RSC Adv., 2017, 7, 42056

Received 18th July 2017

Accepted 15th August 2017

DOI: 10.1039/c7ra07923k

rsc.li/rsc-advances

\section{Mutagenesis and immunological evaluation of group A streptococcal C5a peptidase as an antigen for vaccine development and as a carrier protein for glycoconjugate vaccine design $\dagger$}

\author{
Hui Li, ${ }^{a}$ Subo Wang, ${ }^{a}$ Yisheng Zhao, ${ }^{a}$ Zonggang Chen, ${ }^{a}$ Guofeng Gu (DD *a \\ and Zhongwu Guo (D) *ab
}

\begin{abstract}
A truncated form (AA32-1032) of group A streptococcus (GAS) C5a peptidase (ScpA), an important GAS virulence factor, and its mutants were prepared and examined to find suitable GAS vaccine candidates and conjugate vaccine carriers. Enzymatic evaluation of the recombinant proteins with a MALDI-TOF MS-based method to analyze the reaction indicated that D130 and N295 were not critical for its activity and $\mathrm{S} 512$ was significant but not absolutely required either. Therefore, $\triangle \mathrm{Scp} A^{\mathrm{D} 130 \mathrm{~A}}, \triangle \mathrm{S} \mathrm{Sp} A^{\mathrm{N} 295 \mathrm{~A}}$ and $\triangle \mathrm{ScpA} \mathrm{A}^{\mathrm{S} 512 \mathrm{~A}}$ were not suitable vaccine and carrier protein candidates due to their remaining enzymatic activity. A single mutation of $\mathrm{H} 193$ to Ala abolished the ScpA activity completely, thereby identifying $\triangle \mathrm{Scp} \mathrm{A}^{\mathrm{H1} 193 \mathrm{~A}}$ as a promising candidate that was subjected to immunological studies in mouse. It was shown to elicit high titers of antigen-specific IgG1 antibodies and robust T cell-mediated immunities, verifying its potential as a GAS vaccine. Moreover, conjugating the trisaccharide repeating unit of GAS polysaccharide with $\triangle \mathrm{S} c \mathrm{PA}{ }^{\mathrm{H} 193 \mathrm{~A}}$ could convert the nonimmunogenic oligosaccharide into a highly active and $T$ cell-dependent antigen, demonstrating the potential of $\triangle \mathrm{Scp} A^{\mathrm{H} 193 \mathrm{~A}}$ as a carrier protein to help formulate robust glycoconjugate vaccines.
\end{abstract}

\section{Introduction}

The Gram-positive bacterium Streptococcus pyogenes, also known as group A streptococcus (GAS), is one of the most common pathogens, which can cause high morbidity and mortality in humans. ${ }^{1,2}$ GAS infections are associated with a variety of human diseases from mild pharyngitis and pyoderma to severe necrotizing fasciitis, pneumonia, and toxic shock syndrome, leading in many cases to fatal poststreptococcal sequelae such as rheumatic fever, rheumatic heart disease, and acute glomerulonephritis. It is estimated that more than 700 million people suffer from GAS infections each year, giving rise to over 500000 annual deaths. ${ }^{3,4}$ The estimated cost of GAS pharyngitis among children is up to US\$220-540 million every year in the United States alone. ${ }^{5}$ To date, there is still no commercial vaccine for GAS, thus antibiotic therapy is the only strategy available to treat its infections. However, the insurgence of antibiotic-resistant bacteria, ${ }^{6}$ together with the

${ }^{a}$ National Glycoengineering Research Center, School of Life Science, Shandong University, 27 Shanda Nan Lu, Jinan 250100, China. E-mail: guofenggu@sdu.edu. cn; zguo@chem.ufl.edu; Tel: +86 (531) 88363612; +1 (352) 3929133

${ }^{b}$ Department of Chemistry, University of Florida, 214 Leigh Hall, Gainesville, Florida 32611, USA

$\dagger$ Electronic supplementary information (ESI) available. See DOI: $10.1039 / \mathrm{c} 7 \mathrm{ra} 07923 \mathrm{k}$ high burden of the diseases, makes the development of new therapeutic and preventative strategies, such as vaccines, for the control of GAS infection in urgent demand.

For the development of GAS vaccines, ${ }^{7-11}$ many past endeavors have been focused on the $\mathrm{M}$ protein, resulting in several vaccine candidates that entered clinic trials. ${ }^{12-15}$ However, the antigenic variability of $\mathrm{M}$ protein (>100 serotypes) and the safety concerns of its immune response to cause potential cross-reaction with human tissues would affect the applicability of related vaccines. ${ }^{1,16}$ Therefore, much current attention has been turned towards other GAS virulence factors, such as its toxins, ${ }^{17}$ polysaccharides, ${ }^{18,19}$ and C5a peptidase, ${ }^{20,21}$ etc.

GAS C5a peptidase (ScpA) is a bacterial cell surfaceassociated peptidase which specifically inhibits the activities of human phagocyte C5a chemotaxin, ${ }^{22,23}$ a key mediator in the process of phagocyte recruitment to the infection site. ${ }^{24}$ ScpA cleaves the peptide bond between residues His67 and Lys68 at the leukocyte-binding site of C5a to result in delaying phagocyte permeation and impeding bacterial clearance from the mucosal surface.$^{25} \mathrm{ScpA}$ is thereby recognized as an important virulence factor of streptococci that mediates their colonization in the host. Moreover, ScpA is antigenically conserved among most human GAS isolates and shares a high homology $(>95 \%)$ with other C5a peptidases from group B, C, and G streptococci. ${ }^{26-28} \mathrm{It}$ was also found that mutagenesis of the catalytic site of ScpA 
could dramatically decrease its enzymatic activity. ${ }^{29,30}$ Therefore, ScpA can be an excellent target antigen for vaccine development.

Indeed, it was demonstrated that intranasal immunization of mice with a truncated ScpA49 protein in the ScpA internal deletion form could induce specific IgA and IgG antibodies and prevent streptococcal colonization. ${ }^{31}$ It was also reported that the sera of healthy human adults contained high titers of antiScpA antibodies that could neutralize the activity of ScpA. ${ }^{32}$ Studies in children further revealed that ScpA was highly immunogenic and the specific immune response could be stimulated irrespective of streptococcal serotypes. ${ }^{21}$

In the meantime, ScpA is also a promising target for the development of carrier proteins for glycoconjugate vaccines owing to its unique immunological properties. According to reports, ${ }^{33,34} \mathrm{ScpB}$, a homologous enzyme from GBS, could act as an effective carrier protein to improve the immunogenicity of GBS polysaccharide. It is well documented that most carbohydrates are poorly immunogenic and $\mathrm{T}$ cell-independent and cannot be directly used as vaccines. ${ }^{35-37} \mathrm{~A}$ conventional strategy used to formulate effective carbohydrate-based vaccines has been to couple carbohydrates with a carrier protein to form glycoconjugates that can have improved immunogenicity and elicit $\mathrm{T}$ cell-dependent carbohydrate-specific immunity. ${ }^{38,39}$ Many antibacterial conjugate vaccines have been successfully developed and commercialized, and the most frequently used carrier proteins in the licensed vaccines were derived from bacterial toxins, such as diphtheria toxoid (DT), tetanus toxoid (TT), a diphtheria toxin mutant CRM197, etc. However, it was reported that long-term use of a carrier protein could cause immunological issues, such as carrier primed enhancement of $\mathrm{T}$ lymphocytes, carrier induced carbohydrate epitope suppression and bystander interference. ${ }^{40-43}$ Consequently, developing new carrier proteins to overcome these problems is currently another important topic.

Inspired by the aforementioned discoveries, we became interested in developing ScpA-based GAS vaccines and using ScpA as a carrier protein of glycoconjugate vaccines. In this regard, it is necessary to find a proper mutant of ScpA that does not have the original enzymatic activity but possesses robust immunostimulant function. Accordingly, a truncated form of ScpA and a series of its mutants were expressed and studied in this research. A mutant protein that was proved to be non-active to the human C5a peptide substrate was identified and evaluated in vivo as a potential GAS vaccine candidate and as a glycoconjugate vaccine carrier.

\section{Results and discussion}

It has been disclosed that ScpA is a protein composed of 1167 amino acids having a catalytic domain at the N-terminus (residues 97-583) and three tandemly arranged fibronectin domains (Fn1, Fn2 and Fn3) at the C-terminus (residues 584-1032). ${ }^{44}$ Its amino acid residues Asp130, His193, and Ser512 in the $\mathrm{N}$-terminal sequence forms a catalytic triad at the active site. Furthermore, the Asn295 residue is involved in the formation of an oxyanion-hole and thus is also considered being critical for its catalytic activity. ${ }^{45}$ Based on these findings, we planned a systematic study on the mutagenesis of ScpA by replacing Asp130, His193, Asn295, and Ser512 at the active site with alanine residues in the truncated form of ScpA containing amino acid residues 32-1032. Therefore, four single-site (Asp130Ala, His193Ala, Asn295Ala, Ser512Ala) and one twosite (Asp130Ala and Ser512Ala) mutants of this protein were prepared and investigated.

\subsection{Expression and purification of recombinant proteins}

The truncated gene of wild-type ScpA encoding amino acid residues 32-1032 and the genes of its mutants with Asp130Ala, His193Ala, Asn295Ala, Ser512Ala, and Asp130Ala/Ser512Ala mutations were synthesized and then inserted into expression vector pGEX-6p-3 between the restriction enzyme cutting sites of BamH I and Xho I by standard protocols. The recombinant plasmids were transferred into Escherichia coli BL21(DE3), and the transformants were cultured in the Luria-Bertani (LB) medium containing ampicillin at $37{ }^{\circ} \mathrm{C}$ overnight. The target proteins should contain the GST-tag at their N-termini. Protein expression was induced by the addition of IPTG $(0.3 \mathrm{mM})$. The cells were continuously cultivated at $16{ }^{\circ} \mathrm{C}$ for $16 \mathrm{~h}$, harvested when the cell culture reached an optical density (OD) value of $c a .1 .0$ at $600 \mathrm{~nm}$, and finally disrupted by ultrasonication. The crude GST-tagged protein was isolated in the supernatant after centrifugation of the cell lysate at $12000 \mathrm{rpm}$ and $4{ }^{\circ} \mathrm{C}$ for $30 \mathrm{~min}$ and was purified to homogeneity by GSTrap affinity chromatography.

The SDS-PAGE results of $\Delta \mathrm{ScpA}^{\mathrm{H} 193 \mathrm{~A}}$ depicted in Fig. 1 showcased the purification process of recombinant proteins. The band of the target protein in accordance with the theoretical mass prediction $(140 \mathrm{kDa})$ of GST-tagged $\Delta \mathrm{ScpA}^{\mathrm{H} 193 \mathrm{~A}}$ was enriched after the initial purification on a GSTrap column (lane 4 and 6, Fig. 1). The GST tag of the purified fusion protein was then cleaved by PreScission protease, a highly restricted enzyme that hydrolyzes amino acid sequence LEVLFQGP between $\mathrm{Q}$ and $\mathrm{G}$, at $4{ }^{\circ} \mathrm{C}$ overnight, affording the recombinant $\Delta \mathrm{ScpA}{ }^{\mathrm{H} 193 \mathrm{~A}}$ protein after GSTrap column separation to remove GST tag (lane 2, Fig. 1). The protein was finally purified with a Q Sepharose anion exchanger column to give a pure protein $(\sim 110 \mathrm{kDa})$ as shown by SDS-PAGE (lane 1, Fig. 1). All other recombinant proteins were purified to homogeneity by the same protocols and procedure.

\subsection{Enzymatic activities of $\Delta S \operatorname{Sep} A$ proteins}

Literature reported methods for assaying the enzymatic activities of ScpA were based upon SDS-PAGE or reverse-phase HPLC analysis. $^{29,30}$ These methods suffer from drawbacks such as relatively low sensitivity and time-consuming operations. Furthermore, the former method also requires a C5a-green fluorescent fusion protein as the substrate. To facilitate the enzymological study of the recombinant $\Delta$ ScpA proteins, we developed herein a simple and very sensitive mass spectrometry-based method to monitor and analyze the enzymatic activity. 


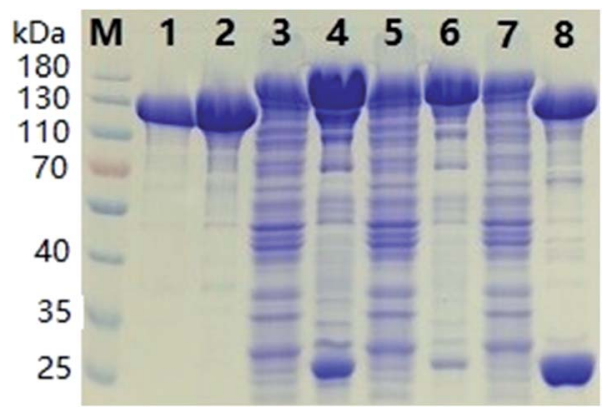

Fig. 1 SDS-PAGE results for $\triangle \mathrm{ScpA} \mathrm{H}^{\mathrm{H} 193 \mathrm{~A}}$ protein purification. Lane 1: purified protein after the $Q$ Sepharose column; lane 2: purified protein after the second GSTrap column; lanes 3, 5 and 7: flow through of the first GSTrap column; lanes 4 and 6: GST-tagged $\Delta \mathrm{ScpA}^{\mathrm{H193A}}$ after the first GSTrap column; lane 8: mixture of the GST tag and $\Delta \mathrm{ScpA}^{\mathrm{H} 193 \mathrm{~A}}$ after treatment with PreScission protease; lane $M$ : protein standards with the molecular weights in $\mathrm{kDa}$ labeled on the left side of the figure.

The human C5a peptide is a 74-amino acid fragment of a complement component, which can be hydrolyzed by the highly restricted ScpA between His67 and Ly68 at the leukocytebinding site, resulting in the cleavage of seven amino acid residues at the C-terminus of C5a peptide and decrease of its molecular weight by about $830 \mathrm{Da} \cdot{ }^{44}$ Commercially available recombinant human C5a peptide was employed in this study to assess the enzymatic activities of $\Delta$ ScpA proteins by matrixassisted laser desorption ionization-time of flight mass spectrometry (MALDI-TOF MS).

Assays of the enzymatic activities of $\Delta \mathrm{ScpA}$ proteins were performed in Tris- $\mathrm{HCl}$ buffer $(50 \mathrm{mM}, 20 \mu \mathrm{L}, \mathrm{pH} 7.5)$ containing $100 \mathrm{mM}$ of NaCl, $5 \mathrm{mM}$ of $\mathrm{CaCl}_{2}$ and $30 \mu \mathrm{g} \mathrm{mL}{ }^{-1}$ of C5a peptide, using different concentrations of each $\Delta$ ScpA protein $(1,3,30$, and $\left.300 \mu \mathrm{g} \mathrm{mL}{ }^{-1}\right)$. The reaction mixture was kept at $20{ }^{\circ} \mathrm{C}$ for $30 \mathrm{~min}$ before it was subjected to MALDI-TOF MS analysis. The MS data were collected in a linear-positive mode using sinapinic acid as the matrix.

As shown in Fig. 2 (trace A and ESI Fig. S1†), under the above mentioned condition, the wild-type $\Delta$ ScpA could completely transform the substrate C5a peptide $(\mathrm{m} / \mathrm{z} \sim 8600 \mathrm{Da})$ into the product $(m / z \sim 7760 \mathrm{Da})$ at the lowest tested concentration (1 $\mu \mathrm{g} \mathrm{mL}^{-1}$ ), verifying its activity. The $\Delta \mathrm{ScpA}^{\mathrm{D} 130 \mathrm{~A}}$ and $\Delta$ ScpA $^{\mathrm{N} 295 \mathrm{~A}}$ mutants (traces B and C, Fig. 2, ESI S2 and S3 $\dagger$ ) could also hydrolyze C5a peptide completely at low concentrations, thus exhibiting similar activities as the wild-type $\Delta$ ScpA. The results suggested that the Asp130 and Asn295 residues might not play a key role in the enzymatic activity of ScpA. No obvious reaction was found with the $\Delta \mathrm{ScpA}^{\mathrm{S} 512 \mathrm{~A}}$ mutant at low concentrations ( 1 and $3 \mu \mathrm{g} \mathrm{mL} \mathrm{m}^{-1}$ ), but its enzymatic activity was evident at high concentrations ( 30 and $300 \mu \mathrm{g} \mathrm{mL} \mathrm{m}^{-1}$ ) (trace $\mathrm{D}$, Fig. 2 and ESI S4 $\uparrow$ ). Similarly, the two-site mutant $\triangle \mathrm{ScpA}^{\mathrm{D} 130 \mathrm{~A}, \mathrm{~S} 512 \mathrm{~A}}$ also showed some enzymatic activity only at high concentrations (trace E, Fig. 2 and ESI S5†). These results demonstrated that the Ser512 residue was important but not absolutely required for the catalytic activity of ScpA. In contrast, the $\Delta \mathrm{ScpA}^{\mathrm{H} 193 \mathrm{~A}}$ mutant exhibited no enzymatic activity at all even at $300 \mu \mathrm{g} \mathrm{mL} \mathrm{m}^{-1}$ concentration (trace F, Fig. 2 and ESI S6 $\dagger$ ),

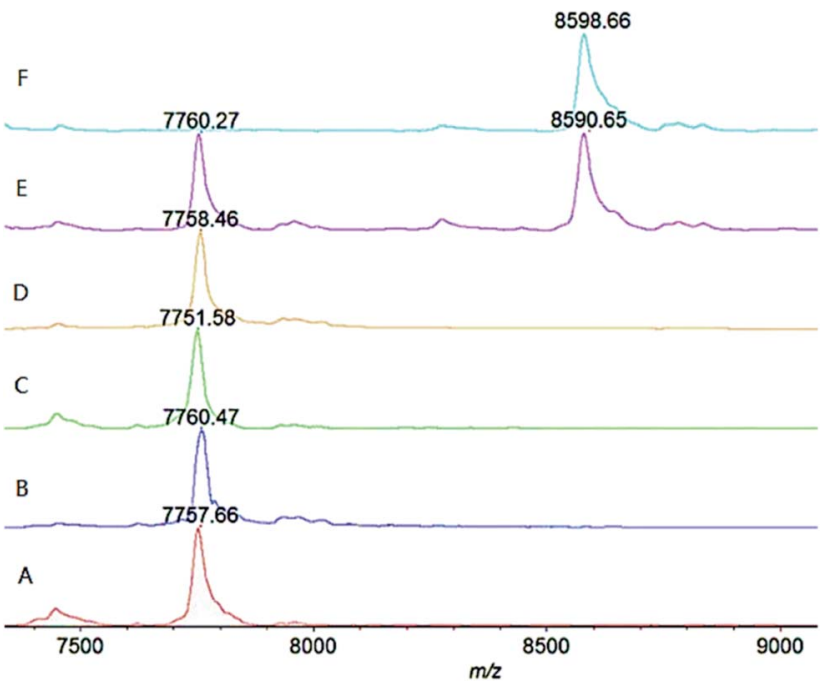

Fig. 2 MALDI-TOF MS results for the hydrolysis of human C5a peptide $\left(30 \mu \mathrm{g} \mathrm{mL}^{-1}\right)$ catalyzed by (A) truncated wild-type $\Delta \mathrm{ScpA}\left(1 \mu \mathrm{g} \mathrm{mL}^{-1}\right)$ and its various mutants, including (B) $\Delta \operatorname{ScpA}^{\mathrm{D} 130 \mathrm{~A}}\left(1 \mu \mathrm{g} \mathrm{mL} \mathrm{m}^{-1}\right.$ ), (C) $\triangle \mathrm{ScpA}^{\mathrm{N} 295 \mathrm{~A}}\left(1 \mu \mathrm{g} \mathrm{mL} \mathrm{mL}^{-1}\right),(\mathrm{D}) \Delta \mathrm{ScpA}^{\mathrm{S} 512 \mathrm{~A}}\left(30 \mu \mathrm{g} \mathrm{mL} \mathrm{mL}^{-1}\right),(\mathrm{E})$ $\Delta \mathrm{ScpA}^{\mathrm{D} 130 \mathrm{~A}, \mathrm{~S} 512 \mathrm{~A}}\left(30 \mu \mathrm{g} \mathrm{mL}^{-1}\right)$ and (F) $\Delta \mathrm{ScpA}^{\mathrm{H} 193 \mathrm{~A}}\left(30 \mu \mathrm{g} \mathrm{mL}^{-1}\right)$, after reaction at $20^{\circ} \mathrm{C}$ for $30 \mathrm{~min}$.

indicating that the His193 residue was crucial for the catalytic activity of ScpA..$^{29}$

\subsection{Immunization of mice with the $\Delta \operatorname{ScpA}^{\mathrm{H} 193 \mathrm{~A}}$ mutant}

The above results showed that His193Ala mutation could completely deactivate $\Delta \mathrm{ScpA}$ and suppress its toxicity. Thus, the $\triangle \mathrm{ScpA}^{\mathrm{H} 193 \mathrm{~A}}$ mutant was selected for immunological evaluations as a potential vaccine candidate using female $\mathrm{C} 57 \mathrm{BL} / 6$ mouse. An emulsion of $\Delta \mathrm{ScpA}^{\mathrm{H} 193 \mathrm{~A}}$ with the complete Freund adjuvant (CFA) for the initial immunization or with the incomplete Freund adjuvant (IFA) for subsequent immunizations was subcutaneously (s.c.) injected to a group of six mice on days 1 , $14,21,28$, and 42 , respectively. Blood samples were collected from these mice prior to and after the immunizations on days 0 and 56 to prepare antisera, which were analyzed by enzymelinked immunosorbent assays (ELISA) to determine ScpAspecific total (anti-kappa), IgM, IgG1, IgG2b, IgG2c, and IgG3 antibodies titers using $\Delta \mathrm{ScpA}^{\mathrm{H} 193 \mathrm{~A}}$ as the capture antigen. Antibody titers were calculated from a linear regression analysis of the curves of the observed optical density (OD) values against serum dilution numbers, and were defined as the dilution number yielding an OD value of 0.2 .

As shown in Fig. 3, the $\triangle \mathrm{ScpA}^{\mathrm{H} 193 \mathrm{~A}}$ protein elicited high titers of mainly antigen-specific IgG, including IgG1, IgG2b and IgG2c, antibodies in all of the six tested mice, suggesting that $\Delta \mathrm{ScpA}^{\mathrm{H} 193 \mathrm{~A}}$ could provoke a robust immune response. The production of higher titers of IgG1, IgG2b and IgG2c antibodies, especially the IgG1 antibody, suggested a $\mathrm{T}$ cell-mediated immune response. ${ }^{46,47}$ These results suggested that $\Delta \mathrm{ScpA}^{\mathrm{H} 193 \mathrm{~A}}$ can be a promising vaccine candidate and a promising carrier protein for glycoconjugate vaccines. 


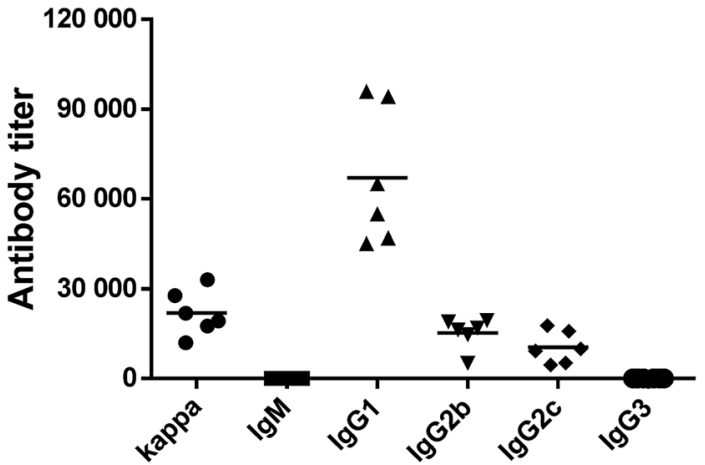

Fig. 3 ELISA results showing the total (anti-kappa) and IgM, IgG1, $\lg G 2 b, \lg G 2 c$, and $\lg G 3$ antibody titers in the day 56 antisera of mice immunized with $\triangle \mathrm{ScpA}{ }^{\mathrm{H1} 193 \mathrm{~A}}$. Each dot represents the result of an individual mouse, and the horizontal bar represents the average of antibody titer for the group of six mice.

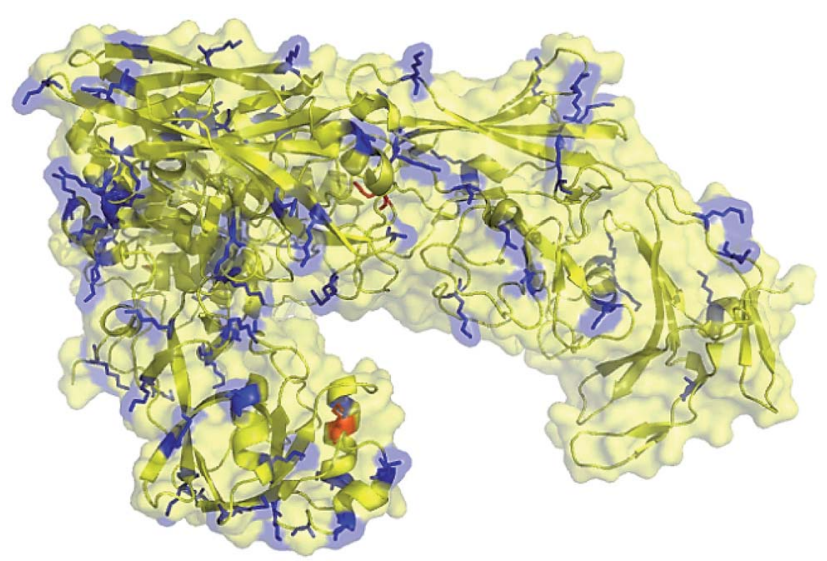

Fig. 4 Predicted Lys residues present on the surface (marked in blue color) of the $\triangle \mathrm{ScPA}{ }^{\mathrm{H} 193 \mathrm{~A}}$ protein.

\subsection{Immunization of mice with GAS trisaccharide-} $\Delta \operatorname{ScpA}^{\mathrm{H193A}}$ conjugate

For the preparation of neoglycoprotein conjugate vaccines, carbohydrate antigens are usually covalently linked to the $\varepsilon$-amino group of lysine residues in the carrier protein through reductive amination, acylation, and various other reactions. Therefore, the number of Lys residues on the molecule surface is an important factor for the carrier protein as this can significantly affect the carbohydrate antigen loading efficiency. To preliminarily evaluate the feasibility of $\Delta \mathrm{ScpA}^{\mathrm{H} 193 \mathrm{~A}}$ as a conjugate vaccine carrier, we calculated and predicted the number of lysine residues present on its surface using the PyMOL software. It was shown that among a total of 87 Lys residues in the structure of $\Delta \mathrm{ScpA}^{\mathrm{H} 193 \mathrm{~A}}$, approximately 30 are on the protein surface (Fig. 4), which can provide a sufficient number of conjugating sites for carbohydrate antigens.

The strong immunological activity of $\Delta \mathrm{ScpA}^{\mathrm{H} 193 \mathrm{~A}}$ to elicit a robust $\mathrm{T}$ cell-mediated immune response and the large number of Lys residues present on its surface to facilitate its conjugation with carbohydrate antigens support the potential of $\Delta \mathrm{ScpA}^{\mathrm{H} 193 \mathrm{~A}}$ as a conjugate vaccine carrier. To investigate and verify this possibility, a nonimmunogenic trisaccharide derivative of the GAS polysaccharide, ${ }^{48,49} \alpha$-L-Rha- $(1 \rightarrow 2)$-[2-deoxy-2acetamido-D-Glc- $(1 \rightarrow 3)]$ - $\alpha$-L-Rha-OCH${ }_{2} \mathrm{CH}_{2} \mathrm{NH}_{2}$ (1), which was fully characterized by the NMR and MS data (ESI Fig. S7 $\dagger$ ), was selected as a carbohydrate hapten. It was conjugated with $\Delta \mathrm{ScpA}^{\mathrm{H} 193 \mathrm{~A}}$ via a di( $N$-succinimidyl)glutarate (DSG) linker (ESI Fig. $\mathrm{S} 8 \dagger$ ), and the immunological properties of resulting trisaccharide- $\Delta \mathrm{ScpA}^{\mathrm{H} 193 \mathrm{~A}}$ conjugate 2 (Fig. 5A) were evaluated in mice. Therefore, each group of six female C57BL/6 mice were respectively immunized through s.c. injection of a CFA/IFA emulsion of conjugate 2 or free GAS trisaccharide 1 on days 1 , 14,21 , and 28, as described above. Blood samples were collected from the mice on day 33 and utilized to prepare antisera by the standard protocol. The antisera were then analyzed by ELISA to determine GAS trisaccharide-specific antibodies using the bovine serum albumin (BSA) conjugate 3 of the same trisaccharide (ESI Fig. S8†) as capture antigen and the linker as a negative control to eliminate its potential influence.

The ELISA results depicted in Fig. 5B showed clearly that while free GAS trisaccharide 1 did not have any immunological activity, its $\Delta \mathrm{ScpA}^{\mathrm{H} 193 \mathrm{~A}}$ conjugate 2 elicited very high titers of carbohydrate antigen-specific total antibodies (Fig. 5B). Our detailed assessment of the antibody isotypes further revealed
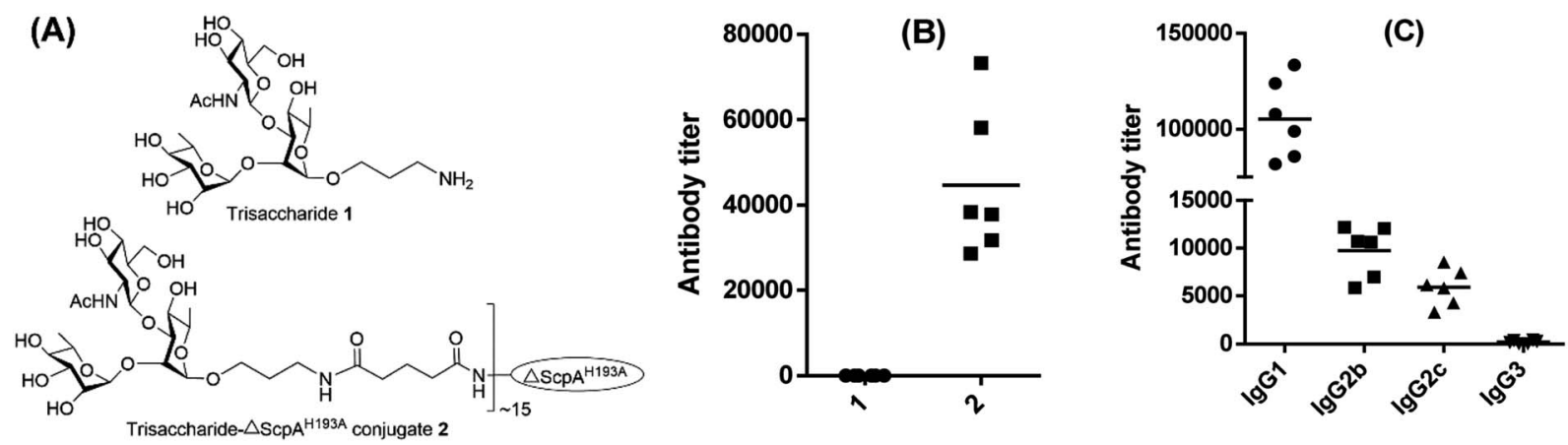

Fig. 5 The chemical structures of (A) the GAS trisaccharide 1 and trisaccharide- $\Delta \mathrm{Scp} \mathrm{A}^{\mathrm{H} 193 \mathrm{~A}}$ conjugate 2, and ELISA results of mouse antisera showing (B) the total (anti-kappa) antibodies elicited by GAS trisaccharide 1 and trisaccharide $-\Delta \mathrm{ScpA}{ }^{\mathrm{H} 193 \mathrm{~A}}$ conjugate 2 , respectively, and (C) IgG1, $\lg G 2 b, \lg G 2 c$ and $\lg G 3$ antibodies elicited by trisaccharide $-\Delta S c p A^{H 193 A}$ conjugate 2 . Each dot represents the result of an individual mouse, and the horizontal bar represents the average antibody titer for each group of six mice. 
that conjugate 2 elicited predominantly IgG antibodies, including IgG1, IgG2b, IgG2c and IgG3, especially IgG1 (Fig. 5C). These results indicated that an immunologically inactive oligosaccharide could be converted into a highly immunogenic antigen after conjugating with $\Delta \operatorname{ScpA}^{\mathrm{H} 193 \mathrm{~A}}$ and the resulting conjugate elicited extremely robust $\mathrm{T}$ cell-dependent immune responses. Consequently, $\Delta \mathrm{ScpA}^{\mathrm{H} 193 \mathrm{~A}}$ was verified in vivo to be a promising carrier protein for the formulation of glycoconjugate vaccines.

\section{Conclusion}

ScpA is one of the promising protein antigens in the development of anti-GAS vaccines and has attracted significant attention in recent years. It was reported that in general the amino acids Asp130, His193, Ser512 and Asn295 of ScpA were critical for its catalytic activities $\mathbf{4 4 , 4 5}^{\mathbf{4}}$ and that its mutants had significantly decreased activity as compared to the wild-type enzyme. ${ }^{29,30}$ It was further discovered that some mutants of truncated ScpA, such as $\Delta \mathrm{ScpA}^{\mathrm{D} 130 \mathrm{~A}, \mathrm{S512A}}$, could induce robust immunities to provide protection against GAS infections. ${ }^{20}$ However, currently systematic studies on the mutagenesis and immunology of this enzyme and its mutants are missing.

In this work, several $\Delta$ ScpA mutants were designed, expressed, and investigated to probe the structure-enzymatic activity relationship of ScpA and its application potential in the development of GAS vaccines and as a carrier protein of glycoconjugate vaccines. To facilitate the evaluation of the enzymatic activities of these recombinant proteins, a MALDI-TOF MSbased simple and sensitive detection method was developed for analyzing the reaction. This assisted to reveal that for the enzymatic activity of ScpA, amino residues D130 and N295 may not be critical and S512, although important, is not absolutely required either because the $\Delta \mathrm{ScpA}^{\mathrm{s512A}}$ mutant still retained some enzymatic activity. These results were different from the literature predictions made on the basis of the ScpA structure as mentioned above. Accordingly, the $\Delta \mathrm{ScpA}^{\mathrm{D} 130 \mathrm{~A}}$ and $\Delta \mathrm{ScpA}^{\mathrm{S} 512 \mathrm{~A}}$ mutants may not be the ideal candidates for vaccine development or other applications. More importantly, we discovered that a single mutation of the amino acid residue $\mathrm{H} 193$ to Ala could completely abolish the enzymatic activity of $\Delta$ ScpA, making its applications safe. Consequently, the $\Delta \operatorname{ScpA}^{\mathrm{H} 193 \mathrm{~A}}$ mutant was selected to conduct further investigations.

The preliminary results of our immunological studies revealed that both $\Delta \mathrm{ScpA}^{\mathrm{H} 193 \mathrm{~A}}$ and its conjugate 2 with the trisaccharide repeating unit of a GAS polysaccharide elicited very high titers of antigen-specific IgG1 antibodies in mice, suggesting the induction of robust $\mathrm{T}$ cell-mediated immune response. Although the strategy to improve the immunogenicity of carbohydrate antigens by forming covalently linked conjugates with various carrier proteins has been widely used in the development of vaccines, the exact mechanism of action is largely unclear. It is believed that the carrier protein may help the processing of carbohydrates by antigen presenting cells, but there is limited data available to verify the hypothesis. ${ }^{\mathbf{5 0 , 5 1}}$ Nevertheless, the results of our immunological studies on $\Delta \mathrm{ScpA}^{\mathrm{H} 193 \mathrm{~A}}$ and its carbohydrate conjugate 2 have demonstrated its great promise in the design and development of novel anti-GAS vaccines and as a carrier protein to help convert immunologically inactive carbohydrates into immunogenic and $\mathrm{T}$ cell-dependent antigens for the formulation of functional conjugate vaccine. To fully exploit this opportunity, more in-depth and extensive immunological, antibody-antigen/ pathogen binding, in vitro and in vivo antibacterial studies are necessary, which are currently pursued in our laboratory.

\section{Materials and methods}

\subsection{Bacterial strains}

The E. coli strains DH5 $\alpha$ and BL21(DE3) were used for the plasmid maintenance and protein expression, respectively. Bacteria were cultured in the LB medium in the presence of antibiotic ampicillin (finial concentration of $100 \mu \mathrm{g} \mathrm{mL} \mathrm{m}^{-1}$ ) under conditions described below in details.

\subsection{Ethical statement}

Female C57BL/6 mice (6-8 week old) were purchased from Shandong University Laboratory Animal Center. All care and handling of animals in this study were performed in strict accordance with the National Institute for Health Guide for the Care and Use of Laboratory Animals (National Research Council, 8th Ed. National Academies Press (US); Washington DC: 2011), and approved by the Institutional Animal Care and Use Committee (IACUC) of Shandong University.

\subsection{Mutagenesis of $\Delta \mathrm{ScpA}$}

Expression vector pGEX-6p-3 carrying the $\Delta$ ScpA gene (bases $96-$ 3096) of $S$. pyogenes B220 encoding amino acid residues 32-1032 was provided as a gift by Professor Jakki C. Cooney's lab in University of Limerick, Ireland. Site-specific mutagenesis of this truncated $\Delta$ ScpA with amino acid residues D130, H193, N295, and S512 substituted with an alanine residue, respectively, was performed with a Fast Mutagenesis System (TransGen Biotech) according to standard protocols. Briefly, using the plasmid pGEX-6p-3 carrying the $\Delta$ ScpA gene as a temple, forward and reverse primers (ESI Table $\mathrm{S} 1 \dagger$ ) were designed, synthesized, and utilized to replace the designated residue. PCR reactions were performed to obtain the amplified fragments, which were then treated with the Dpn I enzyme to remove the template and transformed into E. coli $\mathrm{DH} 5 \alpha$. The mutant plasmids were extracted from $E$. coli, and the mutations were confirmed by gene sequencing. The mutant proteins were expressed in $E$. coli BL21(DE3) host cells.

\subsection{Expression and purification of recombinant proteins}

After recombinant pGEX-6p-3- $\Delta$ ScpA and mutant gene plasmids were transformed into the $E$. coli BL21(DE3) host, the recombinant strains were cultured in the $\mathrm{LB}$ medium at $37{ }^{\circ} \mathrm{C}$ overnight and were allowed to grow to reach an $\mathrm{OD}_{600}$ value of $\sim 1.0$. The cultures were cooled to $16{ }^{\circ} \mathrm{C}$, and then induced with $0.3 \mathrm{mM}$ of isopropyl 1-thio- $\beta$-D-galactoside (IPTG) for another $16 \mathrm{~h}$. The BL21 cells were harvested through centrifugation, and then re-suspended in the binding buffer (50 mM Tris- $\mathrm{HCl}, \mathrm{pH}$ 
8.0, $150 \mathrm{mM} \mathrm{NaCl}$ ), which was followed by disruption with sonication and centrifugation at $12000 \mathrm{rpm}$ and $4{ }^{\circ} \mathrm{C}$ for $30 \mathrm{~min}$ to remove cell debris.

Initial protein purification was achieved via affinity chromatography using a GSTrap column (GE Healthcare Life Sciences Co.). Accordingly, after the cell supernatants obtained above were loaded onto GST trap columns, the columns were washed first with Tris-HCl binding buffer and then with $10 \mathrm{mM}$ glutathione elution buffer (50 mM Tris- $\mathrm{HCl}$ containing $150 \mathrm{mM}$ $\mathrm{NaCl}$ ) to elute GST-tagged target proteins. The protein solution was passed through a Sephadex G-25 column to desalt and remove glutathione with water as the eluent and then treated with PreScission Protease at $4{ }^{\circ} \mathrm{C}$ overnight. The resulting protein solution was loaded again onto a GST trap column, which were washed with Tris-HCl binding buffer to give the GST tag-deleted target protein. The proteins were eventually purified with a strong anion exchanger Q Sepharose column using gradient $\mathrm{NaCl}$ solution $(0-1.0 \mathrm{M})$ in $50 \mathrm{mM}$ Tris- $\mathrm{HCl}$ buffer as an eluent. Protein samples were analyzed with $10 \%$ SDS-PAGE and visualized by Coomassie Brilliant Blue staining. Protein concentrations were determined with a Nanodrop apparatus (Thermo Fisher Inc.) at $280 \mathrm{~nm}$ and calculated according to the Beer-Lambert equation. The proteins were stored in $50 \mathrm{mM}$ Tris- $\mathrm{HCl}$ buffer at $-80^{\circ} \mathrm{C}$.

\subsection{Evaluation of the enzymatic activities of $\Delta \mathrm{ScpA}$ and its mutants}

To a solution of the human C5a peptide $(0.6 \mu \mathrm{g})$ dissolved in $50 \mathrm{mM}$ Tris- $\mathrm{HCl}$ buffer $(\mathrm{pH} 7.5,20 \mu \mathrm{L})$ containing $100 \mathrm{mM}$ of $\mathrm{NaCl}$ and $5 \mathrm{mM}$ of $\mathrm{CaCl}_{2}$ were added varying amounts $(0.02$, $0.06,0.6,6 \mu \mathrm{g})$ of $\Delta \mathrm{ScpA}$ and its mutants. After the solution was incubated at $20{ }^{\circ} \mathrm{C}$ for $30 \mathrm{~min}, 1 \mu \mathrm{L}$ of the reaction mixture was spotted onto a stainless-steel MALDI-TOF MS plate and then covered with sinapinic acid. After solvent was evaporated, the sample plate was subjected to MS analysis with a MALDI-TOF mass spectrometer (AXIMA Confidence, Shimadzu Co.) using the linear-positive mode.

\subsection{Preparation of the GAS trisaccharide-protein conjugates}

A mixture of trisaccahride $\mathbf{1}(2 \mathrm{mg})$ and $\operatorname{di}(N$-succinimidyl $)$ glutarate (DSG, 15 equiv.) in a mixture of DMF and PBS buffer (0.1 M, pH 8.0) (v/v $4: 1,0.5 \mathrm{~mL})$ was gently stirred at rt for $4 \mathrm{~h}$. Thereafter, the solvents were removed under reduced pressure, and ethyl acetate $(4.5 \mathrm{~mL})$ was added to wash the activated ester 10 times and remove excessive DSG. The residue was dried under high vacuum. The activated trisaccharide and $\Delta \mathrm{ScpA}^{\mathrm{H} 193 \mathrm{~A}}$ or BSA (oligosaccharide/protein mass ratio of $2: 3$ ) were dissolved in PBS buffer (0.1 M, 0.5 mL, $\mathrm{pH} 8.0)$, and the solution was gently stirred at rt for 4 days. When analysis by MALDI-TOF mass spectrometry showed no further increase in molecular mass of the conjugate, the reaction mixture was dialyzed against distilled water $(3 \times 8 \mathrm{~mL})$ using an Amicon ulfrafiltration cell equipped with a Diaflo membrane. The residues were subjected to Biogel A0.5 column chromatography and then dialysis against distilled water. The dialysates were lyophilized to give the glycoconjugates $2(2.8 \mathrm{mg})$ and $3(2.5 \mathrm{mg})$, respectively, as white fluffy powders. MALDI-TOF MS data (sinapinic acid matrix, $0.1 \%$ TFA in $1: 1 \quad \mathrm{CH}_{3} \mathrm{CN} / \mathrm{H}_{2} \mathrm{O}$ ): $\Delta$ ScpA $^{\text {H193A }} 110376$ Da (ESI Fig. S9A $\dagger$ ); trisaccharide$\triangle$ ScpA $^{\text {H193A }}$ conjugate 2120868 Da (ESI Fig. S9B $\dagger$ ); BSA 66924 Da (ESI Fig. S10A $\dagger$ ); trisaccharide-BSA conjugate 3 71856 Da (ESI Fig. S10B $\dagger$ ).

The carbohydrate loading of each glycoconjugate was determined by means of MALDI-TOF MS and calculated according to the equation below:

$$
\begin{aligned}
\text { Carbohydrate loading } \%= & \frac{\text { MS of conjugate }- \text { MS of protein }}{\text { MS of conjugate }} \\
& \times 100 \%
\end{aligned}
$$

The results are listed in Table $\mathrm{S} 2 . \dagger$ The carbohydrate loading levels for trisaccharide- $\Delta \mathrm{ScpA}^{\mathrm{H} 193 \mathrm{~A}}$ conjugate 2 and trisaccharide-BSA conjugate 3 were $8.7 \%$ and $6.8 \%(\mathrm{w} / \mathrm{w})$, respectively.

\subsection{Protocols for immunological studies}

Immunization of mice. A solution of $\Delta \operatorname{ScpA}^{\mathrm{H} 193 \mathrm{~A}}(600 \mu \mathrm{g})$, trisaccharide $\mathbf{1}(90 \mu \mathrm{g})$ or trisaccharide $-\Delta \mathrm{ScpA}^{\mathrm{H} 193 \mathrm{~A}}$ conjugate 2 (1.0 $\mathrm{mg}, 8.7 \%$ carbohydrate loading, thus containing $87 \mu \mathrm{g}$ of the trisaccharide antigen) dissolved in $1.5 \mathrm{~mL}$ of $1 \times$ PBS buffer was thoroughly mixed with $1.5 \mathrm{~mL}$ of CFA or IFA according to the manufacturer's instructions to generate an emulsion. Mice (6 each per group) were inoculated first via s.c. injection of $0.1 \mathrm{~mL}$ of the CFA emulsion of a specific conjugate $(20 \mu \mathrm{g}$ of $\Delta \mathrm{ScpA}^{\mathrm{H} 193 \mathrm{~A}}, 3 \mu \mathrm{g}$ of 1 or $35 \mu \mathrm{g}$ of 2 per mouse per injection) on day 1 . Following the initial immunization, the mice were boosted 3 or 4 times on day 14 , day 21 , day 28 , and day 42 via s.c. injection of the IFC emulsion $(0.1 \mathrm{~mL})$ of the same vaccine. Mouse blood samples were collected on day 0 prior to the initial immunization and on day 33 or on day 56 after boost immunizations and were clotted to obtain the antisera by the standard protocols that were stored at $-80{ }^{\circ} \mathrm{C}$ before use.

ELISA. ELISA plates were treated with a solution of $\Delta \mathrm{ScpA}^{\mathrm{H} 193 \mathrm{~A}}$ or GAS trisaccharide-BSA conjugate $3\left(2 \mu \mathrm{g} \mathrm{mL} \mathrm{m}^{-1}\right.$, $100 \mu \mathrm{L}$ per well) dissolved in the coating buffer $(0.1 \mathrm{M}$ aqueous bicarbonate, pH 9.6) at $4{ }^{\circ} \mathrm{C}$ overnight and then at $37^{\circ} \mathrm{C}$ for $1 \mathrm{~h}$. It was followed by washing with PBS buffer containing $0.05 \%$ Tween-20 (PBST) three times. The plates were incubated with the blocking buffer (1\% BSA in PBST, $100 \mu \mathrm{L}$ per well) at rt for $1 \mathrm{~h}$ and washed with PBST three times. Each mouse serum with serial dilutions from 1 : 300 to $1: 4687500$ in PBS $(100 \mu \mathrm{L}$ per well) was added to the coated plates, and the plates were incubated at $37^{\circ} \mathrm{C}$ for $2 \mathrm{~h}$. After being washed with PBST, the plates were incubated with a $1: 1000$ diluted solution of an alkaline phosphatase-linked goat anti-mouse kappa, IgM, IgG1, IgG2b, IgG2c or IgG3 antibody (Abcam), respectively, at rt for $1 \mathrm{~h}$. The plates were again washed with PBST three times and developed with a $p$-nitrophenylphosphate (PNPP) solution $\left(1.67 \mathrm{mg} \mathrm{mL}^{-1}\right.$ in buffer, $100 \mu \mathrm{L}$ ) at $\mathrm{rt}$ for $30 \mathrm{~min}$. The reaction was quenched by adding $25 \mu \mathrm{L}$ of the quenching solution (3 $\mathrm{M} \mathrm{NaOH})$ to each well. Finally, the plates were examined with a microplate reader at $405 \mathrm{~nm}$ wavelength. The OD values after deducting the background OD values obtained with the day 0 sera were plotted 
against dilution numbers, and the best-fit equation was obtained for each set of data and used to calculate the antibody titer, defined as the dilution number giving an adjusted OD value of 0.20 .

\section{Conflicts of interest}

There are no conflicts to declare.

\section{Acknowledgements}

This project was supported by grants from the Shandong Provincial Natural Science Foundation (No. ZR2015BM020) and Science and Technology Development Projects of Shandong Province (No. 2015GSF118019 and 2016GGH4502). We thank Professor Jakki C. Cooney at University of Limerick for kindly supplying expression vector pGEX-6p-3 carrying the $\Delta$ ScpA gene (bases 96-3096) of $S$. pyogenes B220.

\section{References}

1 M. W. Cunningham, Clin. Microbiol. Rev., 2000, 13, 470-511. 2 N. N. Lynskey, R. A. Lawrenson and S. Sriskandan, Curr. Opin. Infect. Dis., 2011, 24, 196-202.

3 J. R. Carapetis, A. C. Steer, E. K. Mulholland and M. Weber, Lancet Infect. Dis., 2005, 5, 685-694.

4 A. P. Ralph and J. R. Carapetis, Curr. Top. Microbiol. Immunol., 2013, 368, 1-27.

5 E. Pfoh, M. R. Wessels, D. Goldmann and G. M. Lee, Pediatrics, 2008, 121, 229-234.

6 K. Wright, Science, 1990, 249, 23-24.

7 WHO, 2005, WHO/FCH/CAH/05.09.

8 A. C. Steer, M. R. Batzloff, K. Mulholland and J. R. Carapetis, Curr. Opin. Infect. Dis., 2009, 22, 544-552.

9 J. B. Dale, V. A. Fischetti, J. R. Carapetis, A. C. Steer, S. Sow, R. Kumar, B. M. Mayosi, F. A. Rubin, K. Mulholland, J. M. Hombach, F. Schodel and A. M. Henao-Restrepo, Vaccine, 2013, S31, B216-B222.

10 M. M. Georgousakis, D. J. McMillan, M. R. Batzloff and K. S. Sriprakash, Expert Rev. Vaccines, 2009, 8, 747-760.

11 A. C. Steer, J. B. Dale and J. R. Carapetis, Pediatr. Infect. Dis. J., 2013, 32, 180-182.

12 S. A. McNeil, S. A. Halperin, J. M. Langley, B. Smith, A. Warren, G. P. Sharratt, D. M. Baxendale, M. A. Reddish, M. C. Hu, S. D. Stroop, J. Linden, L. F. Fries, P. E. Vink and J. B. Dale, Clin. Infect. Dis., 2005, 41, 1114-1122.

13 J. B. Dale, T. A. Penfound, E. Y. Chiang and W. J. Walton, Vaccine, 2011, 29, 8175-8178.

14 M. R. Batzloff, W. A. Hayman, M. R. Davies, M. Zeng, S. Pruksakorn, E. R. Brandt and M. F. Good, J. Infect. Dis., 2003, 187, 1598-1608.

15 L. Guilherme, E. Postol, S. Freschi de Barros, F. Higa, R. Alencar, M. Lastre, C. Zayas, C. R. Puschel, W. R. Silva, L. C. Sa-Rocha, V. M. Sa-Rocha, O. Perez and J. Kalil, Methods, 2009, 49, 316-321.

16 M. W. Cunningham, N. K. Hall, K. K. Krisher and A. M. Spanier, J. Immunol., 1986, 136, 293-298.
17 R. G. Ulrich, J. Immune Based Ther. Vaccines, 2008, 6, 8.

18 H. Sabharwal, F. Michon, D. Nelson, W. L. Dong, K. Fuchs, R. C. Manjarrez, A. Sarkar, C. Uitz, A. Viteri-Jackson, R. S. R. Suarez, M. Blake and J. B. Zabriskie, J. Infect. Dis., 2006, 193, 129-135.

19 A. Kabanova, I. Margarit, F. Berti, M. R. Romano, G. Grandi, G. Bensi, E. Chiarot, D. Proietti, E. Swennen, E. Cappelletti, P. Fontani, D. Casini, R. Adamo, V. Pinto, D. Skibinski, S. Capo, G. Buffi, M. Gallotta, W. J. Christ, A. S. Campbell, J. Pena, P. H. Seeberger, R. Rappuoli and P. Costantino, Vaccine, 2010, 29, 104-114.

20 P. P. Cleary, Y. V. Matsuka, T. Huynh, H. Lam and S. B. Olmsted, Vaccine, 2004, 22, 4332-4341.

21 A. Shet, E. L. Kaplan, D. R. Johnson and P. P. Cleary, J. Infect. Dis., 2003, 188, 809-817.

22 P. P. Cleary, U. Prahbu, J. B. Dale, D. E. Wexler and J. Handley, Infect. Immun., 1992, 60, 5219-5223.

23 H. D. Manthey, T. M. Woodruff, S. M. Taylor and P. N. Monk, Int. J. Biochem. Cell Biol., 2009, 41, 2114-2117.

24 D. E. Wexler, D. E. Chenoweth and P. P. Cleary, Proc. Natl. Acad. Sci. U. S. A., 1985, 82, 8144-8148.

25 Y. Ji, L. McLandsborough, A. Kondagunta and P. P. Cleary, Infect. Immun., 1996, 64, 503-510.

26 P. P. Cleary, J. Handley, A. N. Suvorov, A. Podbielski and P. Ferrieri, Infect. Immun., 1992, 60, 4239-4244.

27 P. P. Cleary, J. Peterson, C. Chen and C. Nelson, Infect. Immun., 1991, 59, 2305-2310.

28 I. Chmouryguina, A. Suvorov, P. Ferrieri and P. P. Cleary, Infect. Immun., 1996, 64, 2387-2390.

29 D. K. Stafslien and P. P. Cleary, J. Bacteriol., 2000, 182, 32543258.

30 E. T. Anderson, M. G. Wetherell, L. A. Winter, S. B. Olmsted, P. P. Cleary and Y. V. Matsuka, Eur. J. Biochem., 2002, 269, 4839-4851.

31 Y. D. Ji, B. Carlson, A. Kondagunta and P. P. Cleary, Infect. Immun., 1997, 65, 2080-2087.

32 S. P. Oconnor, D. Darip, K. Fraley, C. M. Nelson, E. L. Kaplan and P. P. Cleary, J. Infect. Dis., 1991, 163, 109-116.

33 Q. Cheng, B. Carlson, S. Pillai, R. Eby, L. Edwards, S. B. Olmsted and P. Cleary, Infect. Immun., 2001, 69, 2302-2308.

34 Q. Cheng, S. Debol, H. Lam, R. Eby, L. Edwards, Y. Matsuka, S. B. Olmsted and P. P. Cleary, Infect. Immun., 2002, 70, 64096415.

35 J. J. Mond, A. Lees and C. M. Snapper, Annu. Rev. Immunol., 1995, 13, 655-692.

36 H. J. Jennings and R. K. Sood, Synthetic glycoconjugates as human vaccines, in Neoglycoconjugates: Preparation and Applications, ed. Y. C. Lee and R. T. Lee, Academic Press, San Diego, 1994, pp. 325-371.

37 Z. Guo and G.-J. Boons, Carbohydrate-Based Vaccines and Immunotherapies, John Wiley \& Sons, Inc., Hoboken, 2009.

38 C. Anish, B. Schumann, C. L. Pereira and P. H. Seeberger, Chem. Biol., 2014, 21, 38-50.

39 R. Rappuoli and E. De Gregorio, Nat. Med., 2011, 17, 15511552.

40 K. Pobre, M. Tashani, I. Ridda, H. Rashid, M. Wong and R. Booy, Vaccine, 2014, 32, 1423-1430. 
41 R. Dagan, J. Poolman and C. A. Siegrist, Vaccine, 2010, 28, 5513-5523.

42 S. Pecetta, P. Lo Surdo, M. Toritini, D. Proietti, C. Zambonelli, M. J. Bottomley, M. Biagini, F. Berti, P. Costantino, M. R. Romano and S. Grp, Vaccine, 2015, 33, 314-320.

43 M. Tontini, F. Berti, M. R. Romano, D. Proietti, C. Zambonelli, M. J. Bottomley, E. De Gregorio, G. Del Giudice, R. Rappuoli, P. Costantino, G. Brogioni, C. Balocchi, M. Biancucci, E. Malito and S. Grp, Vaccine, 2013, 31, 4827-4833.

44 T. F. Kagawa, M. R. O'Connell, P. Mouat, M. Paoli, P. W. O'Toole and J. C. Cooney, J. Mol. Biol., 2009, 386, 754-772.

45 R. J. Siezen, W. M. de Vos, J. A. Leunissen and B. W. Dijkstra, Protein Eng., 1991, 4, 719-737.
46 T. Mazumdar, K. Anam and N. Ali, Vaccine, 2004, 22, 11621171.

47 T. Mygind, B. Vandahl, A. S. Pedersen, G. Christiansen, P. Hollsberg and S. Birkelund, FEMS Immunol. Med. Microbiol., 2004, 40, 129-137.

48 J. E. Coligan, T. J. Kindt and R. M. Krause, Immunochemistry, 1978, 15, 755-760.

49 D. H. Huang, N. Rama Krishna and D. G. Pritchard, Carbohydr. Res., 1986, 155, 193-199.

50 A. M. Vlad, S. Muller, M. Cudic, H. Paulsen, L. Otvos Jr, F. G. Hanisch and O. J. Finn, J. Exp. Med., 2002, 196, 14351446.

51 B. A. Cobb, Q. Wang, A. O. Tzianabos and D. L. Kasper, Cell, 2004, 117, 677-687. 